\title{
Problem-based Learning and Student Critical Thinking to Improve Learning Achievement at Private Universities in Aceh
}

\author{
Ibrahim1, Nurul Akmal', Marwan3 \\ DOI: $10.35445 /$ alishlah.v13i2.698
}

\begin{tabular}{l}
\hline Article Info \\
\hline Keywords: \\
Learning model; \\
Critical thinking; \\
environmental \\
knowledge and students
\end{tabular}

\begin{abstract}
This study aimed to determine the effectiveness of problem-based teaching and learning models to increase learning achievement and the relationship with students' critical thinking skills. This study used an experimental method with $a$ design pretest-posttest control group. The population in this study were all semester four students of the Biology Education Department. Analysis of experimental data to measure the achievement of student learning outcomes with t-test and critical thinking skills using percentage description analysis, using statistical computer software programs. The research results show an increase in learning achievement, with an average $\mathrm{N}$-gain for problem-based learning units is 70.9 (moderate) and 57.93 (moderate) for conventional classes. The $t$-test results show that the $t$-count value is 3.61 and the $t$-table is 1.991, so $\mathrm{t}$-count> t-table. The conclusion is that there are differences in learning outcomes in implementing problem-based teaching and learning models to increase learning outcomes with critical thinking skills of four at the Private University of Aceh Province, Indonesia.
\end{abstract}

\begin{abstract}
Abstrak
Tujuan penelitian ini adalah untuk mengetahui keefektifan model pembelajaran berbasis masalah (problem-based learning) dalam meningkatkan prestasi belajar dan hubungannya dengan kemampuan berpikir kritis siswa. Penelitian ini menggunakan metode eksperimen dengan desain pretest-postest control group. Populasi dalam penelitian ini adalah seluruh mahasiswa semester empat Jurusan Pendidikan Biologi. Analisis data eksperimen untuk mengukur ketercapaian hasil belajar siswa dengan uji-t dan kemampuan berpikir kritis menggunakan analisis deskripsi persentase, dengan menggunakan program software komputer statistik. Hasil penelitian menunjukkan bahwa terjadi peningkatan prestasi belajar dengan rata-rata Ngain untuk satuan pembelajaran berbasis masalah sebesar 70,9 (sedang) dan kelas konvensional sebesar 57,93 (sedang). Hasil uji-t menunjukkan nilai thitung sebesar 3,61 dan t-tabel sebesar 1,991 sehingga t-hitung > t-tabel. Kesimpulannya adalah terdapat perbedaan hasil belajar penerapan model pembelajaran problem based learning untuk peningkatan hasil belajar keterampilan berpikir kritis mahasiswa Universitas Swasta Provinsi Aceh Indonesia.
\end{abstract}

\footnotetext{
${ }^{1}$ Universitas Serambi Mekkah Banda Aceh Email: ibrahim.sufi@serambimekkah.ac.id 2 Universitas Serambi Mekkah Banda Aceh Email:nurul.akmal@serambimekkah.ac.id

3 Universitas Al Muslim Bireuen

Email: marwan@umuslim.ac.id
} 


\section{INTRODUCTION}

Education is a basic human need in developing and exploring their potential (Fristadi, R. \& Bharata, 2015). The potential that each individual must possess to face global competition in the world of work is an individual who is creative, critical, independent, able to work in a team, communication, independent learning and so on (Kivuja, 2015). For this reason, in facing the challenges of an increasingly modern era, educational institutions have full responsibility to prepare quality human resources (Liliasari, 2011). Furthermore, high-level skills are also said to be one of the skills needed to form quality human resources (Rahmi \& et al., 2020). Regarding this, critical thinking skills are part of higher-order thinking (Agnafia, 2019).

Critical thinking is students' thinking ability, which is very important to be developed, even at the university level. Law 2 of 1989 in Article 16 paragraph 1 explains that higher education is a continuation of secondary educators which are held to prepare the nation's next-generation who have academic and professional potential who can implement, develop, and create knowledge, technology, and arts (Law 2 of 1989 Article 16 Paragraph 1 concerning Higher Education, nd). Thus, an educator is responsible for learning to make students/students active and develop critical and creative thinking skills. It can be done by familiarizing students with learning that requires exploring, inquiry, and solving problems (Sunaryo, 2014).

The implementation of problem-based learning is a strategy to develop active and creative learning to solve problems faced by students from each learning process. In addition, problem-based learning is a curriculum and learning process related to problems commonly experienced by students (Nugraha \& et al., 2017). In this study, a problem design has been made where students know essential principles. They are accustomed to discussing the problem themselves and can participate well with educators/lecturers and group partners (Kurniawan \& Sudrajat, 2018). So that through problem-based learning, students can involve the role of students in independent investigations, can interpret and explain various phenomena they experience during learning activities.

One of the learning activities at the tertiary level of the biology study program is the Environmental Knowledge course. This course provides basic knowledge about the concept of environmental and natural sustainability, including ecology, and can guarantee the preservation of the environmental quality. The aim is to consider aesthetics and needs and ensure the continuity of plants, animals, and valuable materials by creating a balanced cycle in the environment. For this reason, after taking this course, students can describe various interesting facts in protecting the environment, plant, and animal populations so that there is no conflict between animals and humans due to uncontrolled forest encroachment by security forces (Kurniawan \& Sudrajat, 2018 ).

As for the teaching and learning activities carried out in this course, the educators/lecturers present several problems before the lecture begins related to teaching materials for ecology, environmental knowledge, cultivation, and nature conservation in people's daily lives. However, student attendance will influence the problems taught in class with problems directly faced in their lives.

The lecturers found some problems are based on the cooperation between groups and their level of knowledge in seeking information about the nature of plants, the environment, and how to preserve them. So that they can understand the concept and conservation of the environment, they are agents of change who will bring change and apply it in their daily lives. However, in group discussion activities, only a few students participated well during the discussion process by responding and asking questions related to the topic being discussed. In contrast, other students were more likely to be silent and could not respond or refute the discussion topic. This causes the condition of the room to be passive and quiet so that teaching and learning outcomes do not get the quality that is in line with expectations (Ibrahim \& et al., 2020).

For this reason, educators who act as regulators are responsible for providing initiatives for those who tend to be passive to participate in the discussion. One of which is by training or 
familiarizing them to think critically and solve existing problems so that environmental problems such as conflicts between animals, uncontrolled forest encroachment and so on can be resolved. Haryani (2011) states the importance of training students' critical thinking. Throughout learning, students are trained to use critical thinking skills in solving problems, starting from understanding problems, planning solutions, implementing solutions plans to re-evaluate the solutions that have been implemented.

In connection with the above description, the discussion on this topic has been described by Herman (2007). Structured problem-based learning is significantly better than conventional learning in improving high-level mathematical thinking skills of school-based students, differences in qualifications, and students' intelligence. It is known based on the results of experiments to explore the abilities of junior high school students. These different higher-order mathematical thinking abilities are not gender-based. In addition, Herman also described that the mathematical disposition ability of students who received open problem-based learning was better than those who received structured problem-based learning. Besides that, Redhana (2013) also discussed the same topic. He explained that the application of problem-based learning models could improve students' problem-solving and critical thinking skills. He stated that students were very enthusiastic in participating in learning and welcomed this learning model very well. Then, this topic has also been studied by Choridah (2013). His research shows that problem-based learning has a vital role in improving communication skills and creative thinking in expressing ideas and the mathematical disposition of high school students. Another study (Al-Ayubi \& et al., 2018) also states that problembased learning is better than ordinary learning for students' mathematical problem-solving abilities. It is described in his research using descriptive statistics and inferential statistics using the different test of two means. Furthermore, Kenedi \& Helsa (2017) conveyed problem-based learning is one model that can present problems contextually. It can stimulate students' creativity to find concepts and solve problems in everyday life.

Thus, from the various descriptions that have been put forward by the authors that are relevant to this research regarding problem-based learning, which is more dominant in students' mathematical thinking. For this reason, this study seeks to examine problem-based learning in a different scope than before, namely in terms of students' critical thinking at the private higher education level related to environmental conservation contained in environmental education courses. This research is essential for researchers to do to overcome several problems in people's daily lives. In addition, this research can fully contribute to the government in terms of environmental conservation.

\section{METHODS}

This study uses an experimental method. The experimental design used is the Pretestposttest Control Group Design, by conducting experiments in the available classes as they are, without changing the classroom situation and learning schedule. There were two groups of samples studied, namely one experimental group and one control group. Learning with problem-based learning strategies compared to using conventional learning. This design used in this study is a pretest-posttest control group design, which can be seen in the following table (Arikunto, 2006):

\section{Table 1. Pretest-posttest Control Group Design}

\begin{tabular}{llll}
\hline Group & Pre-test & Treatment & Post-test \\
A & $\mathrm{Y}_{1}$ & $\mathrm{X}_{1}$ & $\mathrm{Y}_{2}$ \\
B & $\mathrm{Y}_{1}$ & $\mathrm{X}_{2}$ & $\mathrm{Y}_{2}$
\end{tabular}

This research was conducted at three Aceh Private Universities, namely Pidie, Aceh Besar, and Banda Aceh. This research was conducted in the even semester of the 2019/2020 school year. 
The instruments in this study used instruments, namely: cognitive learning outcomes tests, critical thinking skills instruments that were adapted to the initial research objectives. This study uses an experimental method in the experimental design used in the form of a pretest-posttest control group (Sulistiani \& et al., 2016). The total population involved in this study was 80 fourth-semester students of the Department of Biology Education, FKIP, at three private universities in Aceh Province.

The test of student learning outcomes uses a multiple-choice test with five answer choices. Each correct answer is given a score of 1 , while the questions answered incorrectly are given a score of o. This test helps measure students' cognitive abilities (CI-C6) towards environmental knowledge courses. This study is to determine the cognitive learning outcomes of private university students in Aceh in this course. Environmental knowledge by applying a problem-based learning model with conventional learning with lectures and questions and answers. The results of this study include a pre-test, post-test, and $\mathrm{N}$-gain to determine the increase in cognitive learning outcomes of experimental class students with control class.

Table 2. Pre-test and Post-test Questions

\begin{tabular}{ll}
\hline Indicator & Question Type \\
\hline Analyze the succession process diagram & $\mathrm{C} 4$ \\
Finding the right reason to explain the disturbance & $\mathrm{C} 4$ \\
Environmental balance. & $\mathrm{C} 4$ \\
Examine a food chain. & $\mathrm{C} 4$ \\
Analyzing the impact of breaking the food chain. & $\mathrm{C} 5$ \\
Assessing the government's efforts to punish fish thieves by & $\mathrm{C} 5$ \\
Blow up and sink foreign ships by considering the side effects on aquatic & $\mathrm{C} 5$ \\
ecosystems. & $\mathrm{C} 5$ \\
$\begin{array}{l}\text { Examine environmental policies on river ecosystems polluted by human } \\
\text { activities. }\end{array}$ & $\mathrm{C} 5$ \\
$\begin{array}{l}\text { Find ways to combat fishing by using tiger trawls. } \\
\text { Directing the human lifestyle to reduce the greenhouse effect. }\end{array}$ & $\mathrm{C} 6$ \\
$\begin{array}{l}\text { Designing solutions from reduced environmental carrying capacity. } \\
\text { Create a graph of energy flow in an ecosystem. }\end{array}$ \\
$\begin{array}{l}\text { Selecting organisms that act as trophic level II in the rice field ecosystem. } \\
\text { Explain the changes in the environment due to success }\end{array}$ & $\mathrm{C} 1$ \\
$\begin{array}{l}\text { Summarize the effects of the abundance of nitrogen gas in the air on } \\
\text { organisms on earth. }\end{array}$ & $\mathrm{C} 4$ \\
$\begin{array}{l}\text { Distinguish between energy and matter in an ecosystem. } \\
\text { Defines the most dominant interactions between individuals of the same sex } \\
\text { in obtaining food. }\end{array}$ & $\mathrm{C} 2$ \\
Match organisms to their trophic levels. & $\mathrm{C} 1$ \\
\hline
\end{tabular}

Furthermore, to measure the critical thinking skills of students, the writer uses an observation sheet instrument. The observations made here are in the form of direct observation. That way, the authors directly observe students' critical thinking skills during the implementation of the teaching and learning process in the classroom. Regarding this, four indicators are set as a reference in assigning a value to the observed object. The four categories consist of very good, good, poor, and very poor. Here the authors present the results of observations which are presented in the form of a table below (Ennis, 2012):

Table 3. Indicators of Students' Critical Thinking Skills

\begin{tabular}{lll}
\hline \multicolumn{1}{c}{ No } & Indicators & Sub-indicators \\
\hline 1 & Induce and consider the results of Induction & Raising a problem \\
2 & Consider whether the source is trustworthy or not & Designing problems \\
3 & $\begin{array}{l}\text { Ask and answer } \\
\text { Question }\end{array}$ & Give a simple explanation \\
4 & $\begin{array}{l}\text { Observing and } \\
\text { considering the results }\end{array}$ & Reporting observations \\
5 & Define terms and consider a definition & $\begin{array}{l}\text { Presenting a conclusion } \\
\text { Give examples }\end{array}$ \\
\hline
\end{tabular}


Data processing techniques for students' critical thinking skills using statistics with the following percentage formula (Arikunto, 2020):

$$
\mathrm{P}=\frac{F}{N} \times 100 \%
$$

In providing an interpretation starting from the most significant number to the smallest number (Sugiono, 2006) with the criteria as shown in Table 4 below (Sugiyono, 2006):

Table 4. Percentage Assessment of Critical Thinking Skills

\begin{tabular}{ll}
\hline Level of Assessment & Criteria \\
\hline Bad & $25 \%-43,75 \%$ \\
\hline Poor & $43,76 \%-62,50 \%$ \\
\hline Good & $62,51 \%-81,25 \%$ \\
\hline Excellent & $81,26 \%-100 \%$ \\
\hline
\end{tabular}

\section{Learning Outcome Data Analysis}

The data obtained in pre-test and post-test results were analyzed by comparing the experimental class with the control. The difference between the pre-test and post-test scores was calculated by subtracting the post-test scores and pre-test scores, after which the gain was normalized using the gain normalization formula, namely:

\section{Hypothesis testing}

Hypothesis testing on the difference in the increase in cognitive learning outcomes (data $\mathrm{N}$ Gain) statistically through paired observation t-test is used to compare the increase in cognitive learning outcomes (Score N Gain). Testing The t-test used is the Independent Sample t-test with the following formula (Ruseffendi, 1989):

$$
t=\frac{\bar{x}-\bar{y}}{\sqrt{s^{2} x y\left(\frac{1}{N x}+\frac{1}{N y}\right)}}
$$

The test criteria are to accept Ho if $\mathrm{t}$-count $\mathrm{t}$-table with $\mathrm{dk}=\mathrm{n} 1+\mathrm{n} 2-1$ at a significant level of 0.05 (5\%) and reject $\mathrm{Ha}$ if $\mathrm{t}$-count $>\mathrm{t}$-table.

\section{FINDINGS AND DISCUSSION}

Values in cognitive learning about the existing problems, this study uses pre-test and posttest questions to achieve student learning outcomes of Biology Education, Teacher Training and Educational Sciences at Aceh Private Universities. There is a difference in the -Gain score between the pre-test and post-test which is shown in the following table. 


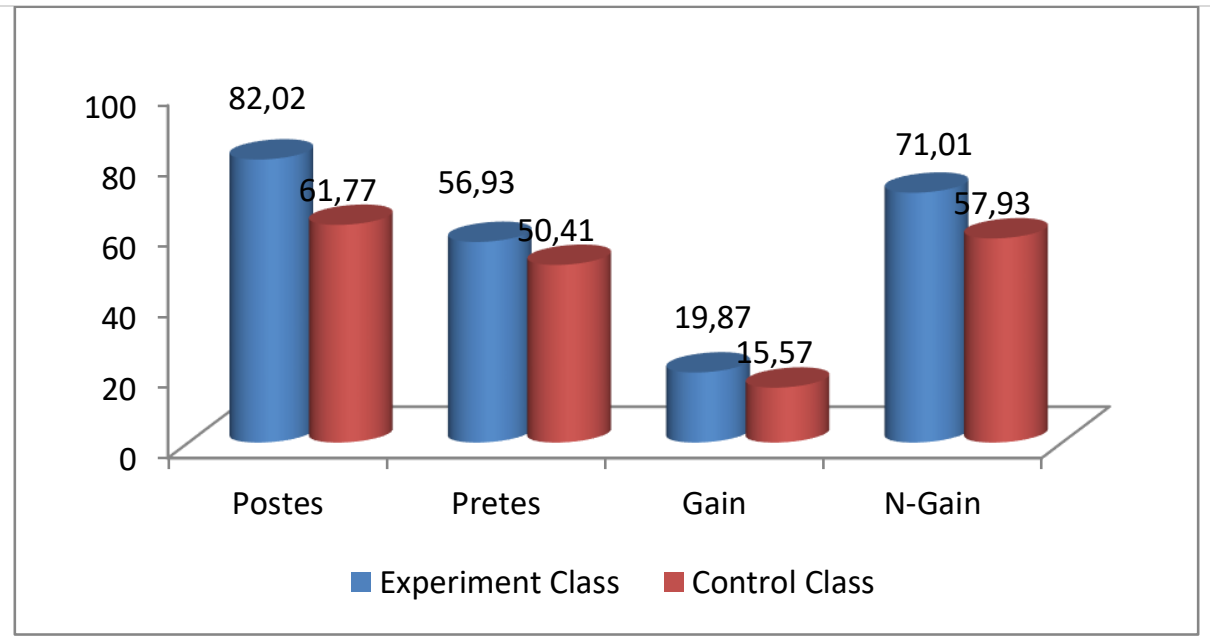

\section{Figure 1. The difference between the value of the experimental class and the control class}

Figure 1 above shows that the experimental unit students' post-test cognitive abilities are higher than the control unit. The experimental unit's post-test score of students' cognitive abilities was 82.02, while the control unit was 62.04. In essence, the average $\mathrm{N}$-Gain value of the experimental unit is 71.01 in the medium criteria, while the control unit is 58.03 in the medium criteria. From the data above, it can be seen that the two groups tested. There was an increase in the average student learning outcomes in environmental knowledge courses at the Teaching Faculty, Private Universities of Aceh Province. Therefore, teaching and learning activities in the experimental unit are more effective using Problem Basic Learning than teaching and learning conventionally. With the difference in cognitive learning outcomes between the experimental unit and the control unit, the environmental knowledge learning process results from a process carried out in a dosed manner to students with different models (Nurdiansyah, 2016).

Learning activities take place using a problem-based learning model in unit one. The lecturer briefly explains the environmental science teaching material then students discuss environmental problems in their respective groups. Lecturers use critical thinking observation papers to collect primary data on critical thinking during the teaching and learning process. While learning activities in the control unit occur conventionally, one of the lecturers opens lectures with lectures, short notes, and questions and answers about environmental knowledge. Students are given time to ask colleagues or lecturers. Therefore, student activity becomes low in participating in learning because it is less challenged, does not arouse students' reasoning, the interaction process is all in one. Such learning conditions must influence students' cognitive learning outcomes to differentiate between the two learning units above. The two problems above are that the teaching and learning model with a problem-based learning model greatly affects student learning outcomes in environmental knowledge courses. This is relevant to research conducted (Sulastri \& et al., 2015) that using problem-based learning strategies in social studies subjects can improve student learning outcomes, with the percentage of success reaching $80.77 \%$. The same thing was also stated (Amir, 2018) that the learning tools that are contextual-based learning tools developed are of good quality, one of which can be seen from the completeness of students' metacognition learning outcomes classically achieved. Students' metacognitive abilities show better awareness of planning, monitoring, and evaluating the problem-solving process during and after the problem-based learning process.

\section{Students' Critical Thinking Ability}

Referring to the course activities of ecology, morphology, basic science, and environmental knowledge, students must fully involve students in their studying problems. According to the view 
(Ramdani, 2018), students can provide arguments to ask and answer questions independently and discover the concepts of environmental and ecological science principles through further research activities to find learning and improve critical thinking skills for students. Critical thinking ability is an initial capital for students that must be developed and possibly improved, especially in teaching materials about environmental knowledge, general biology, plant and animal populations which are very important in human survival as a food source. Furthermore, the value of critical thinking skills can be seen in Table 5 below.

Table 5. Students' Critical Thinking Skills Based on Indicators

\begin{tabular}{|c|c|c|c|c|c|c|c|c|}
\hline \multirow[t]{2}{*}{ Sub Indicator } & \multicolumn{2}{|c|}{ Meeting 1} & \multicolumn{2}{|c|}{ Meeting 2} & \multicolumn{2}{|c|}{ Meeting 3} & \multirow[t]{2}{*}{ Average } & \multirow{2}{*}{ Criteria } \\
\hline & (\%) & Criteria & (\%) & Criteria & (\%) & Criteria & & \\
\hline $\begin{array}{l}\text { Bringing up } \\
\text { problems }\end{array}$ & 71.1 & Good & 72.3 & Good & 76.8 & Good & 72.8 & Good \\
\hline $\begin{array}{l}\text { Design the } \\
\text { problem }\end{array}$ & 65.2 & Good & 84.2 & $\begin{array}{l}\text { Very } \\
\text { Good }\end{array}$ & 87.6 & $\begin{array}{l}\text { Very } \\
\text { Good }\end{array}$ & 79.0 & Good \\
\hline $\begin{array}{l}\text { Give simple } \\
\text { explanation }\end{array}$ & 76.8 & Good & 81.3 & $\begin{array}{l}\text { Very } \\
\text { Good }\end{array}$ & 85.7 & $\begin{array}{l}\text { Very } \\
\text { Good }\end{array}$ & 80.7 & Good \\
\hline $\begin{array}{l}\text { Report the result } \\
\text { of observation }\end{array}$ & 74.2 & Good & 80.2 & Good & 83.2 & $\begin{array}{l}\text { Very } \\
\text { Good }\end{array}$ & $85 \cdot 3$ & $\begin{array}{l}\text { Very } \\
\text { Good }\end{array}$ \\
\hline $\begin{array}{l}\text { Explain the } \\
\text { conclusion }\end{array}$ & 62.1 & Good & 74.2 & Good & 91.5 & $\begin{array}{l}\text { Very } \\
\text { Good }\end{array}$ & 77.0 & Good \\
\hline $\begin{array}{l}\text { Mention } \\
\text { example }\end{array}$ & 79.3 & Good & 80.5 & Good & 90.3 & $\begin{array}{l}\text { Very } \\
\text { Good }\end{array}$ & 84.2 & $\begin{array}{l}\text { Very } \\
\text { Good }\end{array}$ \\
\hline Average & 69.10 & & 72.0 & & 88.5 & & $96 \%$ & \\
\hline
\end{tabular}

The results from table 5 show that the percentage of results and indicators of students' critical thinking skills from each session has increased. The results of data processing per cent on each indicator of critical thinking look different. The critical thinking indicator with the highest percentage is reporting the results of observations of $85.3 \%$ with very good criteria, and an increase in session I with good criteria by $76 \%$ increasing to $83.1 \%$, being in very good criteria then in session three increasing to $93.2 \%$ are in very good criteria. Furthermore, the lowest per cent indicator provides a simple explanation of $76.2 \%$ on the suitable criteria. The average score for all indicators of students' critical thinking is $96 \%$.

The picture that shows the improvement for each critical thinking skill indicator is more clearly seen in the following graph.

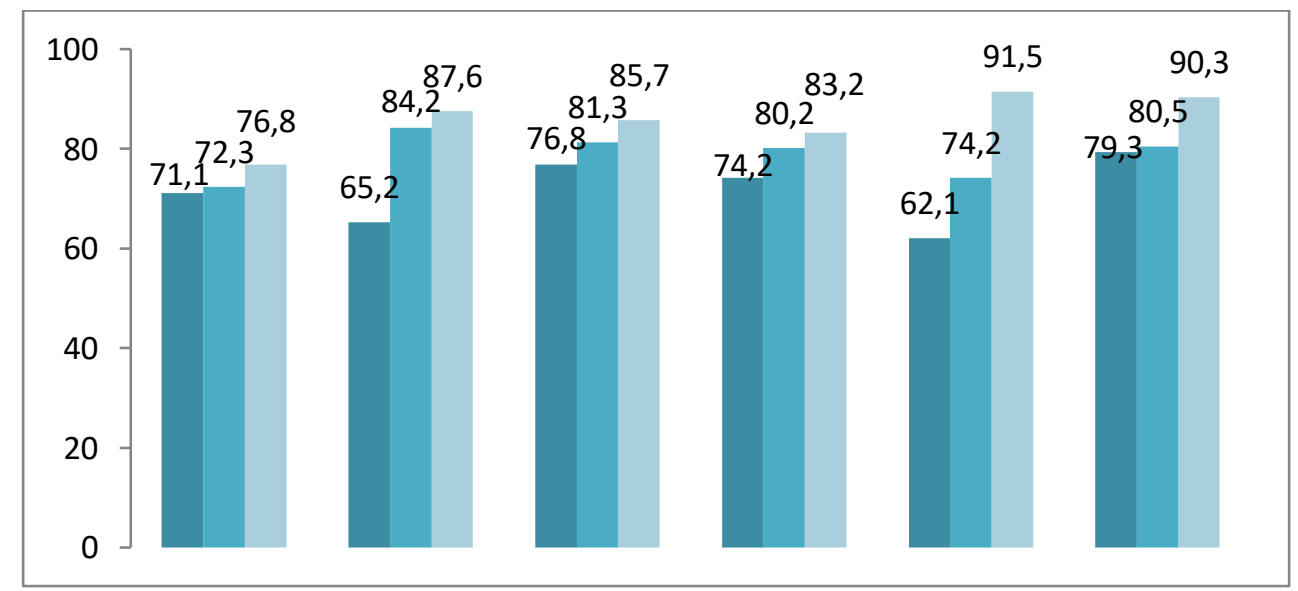

Figure 2. Comparison Phase Percentage of Critical Thinking Skills Based on Indicator 
Figure 2 above shows that the percentage increase in each indicator of critical thinking skills in students of the biology faculty of the Aceh private faculty. However, in general, the use of the PBL model affects increasing students' critical thinking skills in environmental knowledge courses at the Private University of Aceh Province. So the results of this study indicate that each student can express problems and make reports about the results of his observations during the lecture period on environmental knowledge on the criteria of being very good at critical thinking. Then, on the problem design indicators, provide simple arguments, make decisions, and real examples in good criteria. Therefore, students need to continue to train themselves to be more prominent in higher-order thinking to solve learning problems, get new ideas or ideas, correct decisions from correct analysis results. The logic in critical thinking is logical and reasonable, focused on making decisions about what students or laypeople believe and do (Ibrahim et al., 2018). According to (Ernalis \& et al., 2016), in critical thinking, mental and mental cooperation is well organized and plays a role in solving problems by analyzing and interpreting data in more profound learning activities. On the other hand, critical thinking is a valuable skill for improving learning outcomes towards students' scientific attitudes as an intellectual trait.

As stated by Ahmatika (2017) and (Kesuma et al., 2011), critical thinking applies rationality to higher-order thinking by analyzing data and facts based on the phenomenon of solving, evaluating, and making decisions quickly. PBL learning models and critical thinking skills can be improved because there is a process of analysis, drawing conclusions and mentioning concrete examples. Furthermore, from the view (Ibrahim et al., n.d.) that one of the indicators of critical thinking in students is determining solutions and making accurate decisions in fast situations. However, based on the analysis of the percentage of students' critical thinking skills using a correlation regression test to determine how much influence learning outcomes have with critical thinking skills in environmental knowledge lectures. Comply with learning outcomes (N-Gain) as the independent variable $(\mathrm{X})$ and the value of critical thinking skills as the dependent variable $(\mathrm{Y})$. Table 3 shows the results of the significance test.

\section{Relationship between Critical Thinking Skills and Learning Outcomes}

The relationship between critical thinking skills and learning outcomes is also visible, and the direction of the regression equation is Graph 3.

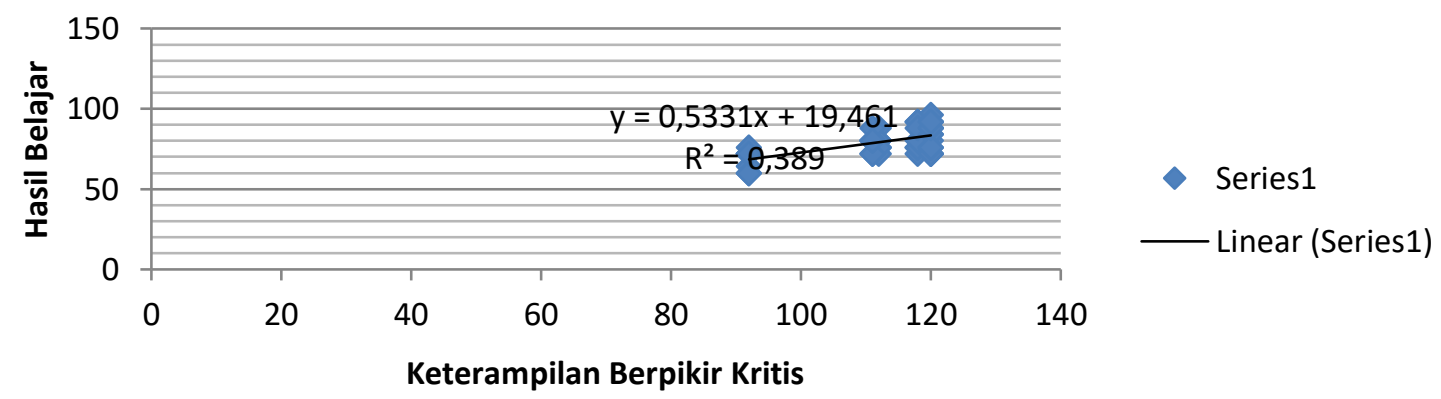

\section{Figure 3. Regression Line Graph}

Figure 3 can explain the direction of the regression between 2 variables. This equation is by the data obtained so that a scattering diagram is formed, and the scattering forms a straight line with the equation $\mathrm{Y}=0.533 \mathrm{x}+19.46$. After obtaining the equation, the correlation is calculated as in table 6 below.

Table 6. The Correlation Test Results Between Critical Thinking Skills and Learning Outcomes

\begin{tabular}{ccccc}
\hline Group & $\begin{array}{c}\text { Critical Thinking } \\
\text { Skills }\end{array}$ & $\begin{array}{c}\text { Learning } \\
\text { outcomes }\end{array}$ & Correlation (r) & $\begin{array}{c}\text { Determinant } \\
\text { coefficient }\left(\mathrm{R}^{2}\right)\end{array}$ \\
\hline Nilai & 5035 & 3560 & 0.64 & 0.39 \\
\hline
\end{tabular}


The use of PBL learning contributes significantly to student learning outcomes and improves students' critical thinking skills. Critical thinking skills are essential things that a student must have in order to be able to organize and know the extent of the steps or preparations that must be done during the practicum activity process. A student who has a good strategy of the course student will get maximum learning outcomes. In connection with this description, (Sumartini 2016) also stated that problem-based learning was better than students who received conventional learning. The same thing was also expressed (Herman, 2007) that students' higher-order thinking skills improved more with problem-based learning than conventional learning.

\section{CONCLUSION}

Based on the description described above, it can be concluded that the application of problembased learning can improve students' critical thinking skills and student learning outcomes in environmental science courses at private universities in Aceh compared to conventional learning. By applying problem-based learning, students can fully contribute to the government's environmental conservation in particular. For this reason, critical thinking is as initial capital for students that must be developed and possibly improved, especially in teaching materials about environmental knowledge, general biology, plant and animal populations which are very important in human survival as a food source.

\section{REFERENCES}

Agnafia, D. N. (2019). Analisis Kemampuan Berpikir Kritis Siswa dalam Pembelajaran Biologi. Florea, Vol. 6 No., 45-53.

Ahmatika, D. (2017). Peningkatan kemampuan berpikir kritis siswa dengan pendekatan inquiry/discovery. Euclid. https://doi.org/https://doi.org/10.33603/e.v3i1.324

Al-Ayubi, I. I., \& Dkk. (2018). Pengaruh Pembelajaran Berbasis Masalah Terhadap Kemampuan Pemecahan Masalah Matemastis Siswa SMA. JPMI: Jurnal Pembelajaran Matematika Inovatif, Vol.1 No.3, 255-360.

Amir, M. F. (2018). Pengembangan Perangkat Pembelajaran Berbasis Masalah Konstektual untuk Meningkatkan Kemampuan Metakognisi Siswa Sekolah Dasar. Journal of Medives: Journal of Mathematics Education IKIP Veteran Semarang, Vol. 2 No., 117-128.

Arikunto, S. (2006). Metode Penelitian Kualitatif. Bumi Aksara.

Arikunto, S. (2020). Prosedur Penelitian Suatu Pendekatan Praktis. Rineka Cipta.

Choridah, D. T. (2013). Peran Pembelajaran Berbasis Masalah Untuk Meningkatkan Kemampuan Komunikasi dan Berpikir Kreatif Siswa serta Disposisi Matematika Siswa SMA. Infinity: Jurnal Ilmiah Program Studi Matematika STKIP Siliwangi Bandung, Vol.2 No.2, 194-202.

Ennis, R. H. (2012). Goals for A Critical Thinking Curriculum, Developing Minds: A Resource Book for Teaching Thinking. Virginia: ASCD.

Ernalis, \& Dkk. (2016). Pengembangan Model Bahan Ajar Bahasa Indonesia Berbasis Model Pembelajaran Yang Berorientasi Pada Pendidikan Karakter. Jurnal Pendidikan Dasar Kampus Cibiru. https://doi.org/https://doi.org/10.17509/EH.V5I1.2832.G1853

Fristadi, R. \& Bharata, H. (2015). Meningkatkan Keampuan Berpikir Kritis Siswa dengan Problem Based Learning, Prosiding: Seminar Nasional Matematika dan Pendidikan Matematika. Universitas Negeri Yogyakarta, 597-602.

Haryani, D. (2011). Pembelajaran Matematika dengan Pemecahan Masalah untuk Menumbuhkembangkan Kemampuan Berpikir Kritis Siswa. Prosiding Seminar Nasional Penelitian, Pendidikan Dan Penerapan MIPA, 20-29.

Herman, T. (2007). Pembelajaran Berbasis Masalah untuk Meningkatkan Kemampuan Berpikir Matematis Tingkat Tinggi Siswa Sekolah Menengah Pertama. Educationist, Vol. 1 No., 47-56.

Ibrahim, Akmal, N., Marwan, \& Hasan, S. (2018). Penerapan model pembelajaran berbasis masalah untuk meningkatkan hasil belajardanberpikir kritisma hasiswa. Jurnal Serambi Ilmu, Vol. 30 No, 120-127.

Ibrahim, \& Dkk. (2020). Implementation of problem-based learning to improve students' critical thinking skills. Journal of Physics: Conference Series, Vol. 146 N.

Ibrahim, Yusoff, N., Awang, M. ., \& Marwan. (n.d.). Learning of reproduction system with an integrative curriculum approach in junior high school. Journal of Physics: Conference Series. 
https://doi.org/https://doi.org/10.1088/1742-6596/1088/1/012013

Kenedi, A. K., \& Helsa, Y. (2017). Literasi Matematika dalam Pembelajaran Berbasis Masalah. Seminar Nasional Pendidikan Guru Sekolah Dasar: Pembelajaran Literasi Lintas Disiplin Ilmu Ke-SD-An.

Kesuma, D., Triatna, C., \& Permana, J. (2011). Pendidikan Karakter: Kajian Teori dan Praktik di Sekolah. Remaja Rosdakarya.

Kivuja, C. (2015). Teaching students to learn and to work well with century skills: unpacking the career and life skills domain of the new learning paradigm. International Journal of Higher Education, Vol. 4 No., 2-11.

kurniawan, Y., \& Sudrajat, A. (2018). Peran teman sebaya dalam pembentukan karakter siswa Madrasah Tsanawiyah. SOCIA: Jurnal Ilmu-Ilmu Sosial, Vol.15 No.

Liliasari. (2011). Peningkatan Kualitas Guru Sains Melalui Pengembangan Keterampilan Berpikir Tingkat Tinggi. Seminar Nasional Pascasarjana.

Nugraha, A. ., \& Dkk. (2017). Analisis Kemampuan Berpikir Kritis Ditinjau dari Keterampilan Proses Sains dan Motivasi Belajar melalui Model PBL. Journal Of Primary Education, Vol. 6 No., 209-218.

Nurdiansyah, F. (2016). Biological control in Indonesian oil palm potentially enhanced by landscape context. Agriculture, Ecosystems and Environment.

Rahmi, R., \& Dkk. (2020). Relevance of bahasa Indonesia Main Materials with HOTS (Higher Order Thinking Skills). Al-Bidayah: Jurnal Pendidikan Dasar Islam, Vol. 12 No, 83-96.

Ramdani, E. (2018). Model pembelajaran kontekstual berbasis kearifan lokal sebagai penguatan Pendidikan Karakter. Jupiis: Jurnal Pendidikan Ilmu-Ilmu Sosial, Vol. 10 No. https://doi.org/https://doi.org/10.24114/jupiis.v10i1.8264

Redhana, W. I. (2013). Model Pembelajaran Berbasis Masalah untuk Peningkatan Keterampilan Pemecahan Masalah dan Berpikir Kritis. Jurnal Pendidikan Dan Pengajaran, Vol.46 No., 76 86.

Ruseffendi, E. . (1989). Dasar-Dasar Penelitian Pendidikan dan Bidang Non Eksakta Lainnya. IKIP Semarang Press.

Sugiyono. (2006). Metode Penelitian Kuantitatif, Kualitatif, dan R \& D. Alfabeta.

Sulastri, \& Dkk. (2015). Meningkatkan Hasil Belajar Siswa Melalui Strategi Pembelajaran Berbasis Masalah pada Mata Pelajaran IPS di Kelas V SDN 2 Limbo Makmur Kecamatan Bumi Raya. Jurnal Kreatif Online, Viol. 3 No.

Sulistiani, E., \& Dkk. (2016). Analisis Kemampuan berpikir Kritis Siswa Lintas Minat Pada Pembelajaran Biologi Kelas X IIS SMA Negeri 11 Kota Jambi. BIODIK: Jurnal Ilmiah Pendidikan Biologi, Vol. 2 No.

Sumartini, T. S. (2016). Peningkatan Kemampuan Pemecahan Masalah Matematis Siswa Melalui Pembelajaran Berbasis Masalah. Mosharafa: Jurnal Pendïdkan Matematika, Vol. 5 No., 148158.

Sunaryo, Y. (2014). Model Pembelajaran Berbasis Masalah Untuk Meningkatkan Kemampuan Berpikir Kritis Dan Kreatif Matematik Siswa SMA Di Kota Tasikmalaya. Jurnal Pendiidkan Dan Keguruan, Vol. 1 No., 41-51.

UU 2 Tahun 1989 Pasal 16 Ayat 1 Tentang Pendidikan Tinggi. (n.d.). 